\title{
Penggunaan Pencekam Tiga Aksis untuk Alat Bantu Pengelasan Rangka Furnitur
}

\author{
(The Use of Three-Axis Clamp for welding Furniture Frames)
}

Rela Adi Himarosa ${ }^{a}$, Muhammad Arif Darmawan ${ }^{b}$, Muhammad Budi Nur Rahman ${ }^{c}$

a,b,c burusan Teknik Mesin, Fakultas Teknik, Universitas Muhammadiyah Yogyakarta Jalan Brawijaya, Tamantirto, Bantul, Indonesia

(0274) 387656

arela.himarosa@umy.ac.id

\begin{abstract}
Abstrak
Distorsi logam terjadi akibat kontraksi logam yang terpapar suhu tinggi sehingga menimbulkan tarikan atau dorongan pada benda kerja. Alat bantu berupa pencekam banyak digunakan pada proses pengelasan untuk mencegah distorsi pada logam. Pencekam tiga aksis mampu melakukan proses pencekaman ketiga aksis sumbu sekaligus. Proses penggunaan pencekam jenis ini sangat bermanfaat untuk proses pengelasan rangka furnitur. Pencekam ini digunakan untuk meningkatkan efisiensi produksi rangka kursi. Penelitian ini untuk mengkaji pemanfaatan pencekam tiga sumbu untuk menahan fenomena distorsi akibat kenaikan suhu proses pengelasan, dan peningkatan produktifitas waktu proses penyambungan dengan variasi arus pengelasan 50 Ampere dan 60 Ampere. Kinerja pencekam mampu mempercepat waktu proses 19\% dan menekan biaya pembuatan produk rangka sebesar $43,74 \%$.
\end{abstract}

Kata kunci: pencekam, pengelasan, distorsi, produktifitas

\begin{abstract}
Metal distortion occurs due to metal contractions exposed to high temperatures that cause pull or push on the work piece. The tools in the form of a grip are widely used in the welding process to prevent metal distortion. The fixture of three axis is capable of holding the three axis at once. The process of using this type of fixture is very useful for the welding process of furniture frames. This grip is used to improve the efficiency of the production of chair frames. This study is to examine the use of three axis fixture to withstand the phenomenon of distortion due to the increase in the temperature of the welding process, and increase the productivity time of the joining process with a variation of welding current of 50 Amperes and 60 Amperes. The fixture performance was able to speed up processing time by $19 \%$ and reduced the cost of making frame products by $43.74 \%$.
\end{abstract}

Keywords: vise, welding, distortion, productivity

\section{Pendahuluan}

Penggunaan alat bantu pencekam atau ragum (vise) sangat penting di dunia manufaktur terutama pengelasan [1], [2]. Alat bantu pencekam memudahkan pembuatan dan mempercepat waktu proses produksi seperti pemegang (jig) dan alat penyesuaian (fixture) [3]. Alat tersebut menjaga konsistensi bentuk, ukuran, konsistensi menjaga kualitas yang seragam dalam industri manufaktur [2]. Produktifitas mampu ditingkatkan dan beban operator tidak terlalu tinggi, karena proses pekerjaan produksi menjadi lebih ringan dengan mengurangi waktu pengecekkan, penandaan, penempatan [4] .Pekerjaan pengelasan merupakan kegiatan produksi manufaktur yang menuntut adanya penggunaan alat bantu. Proses pengelasan memerlukan alat pemegang dan alat untuk menyesuaikan posisi daerah las (welding fixture), alat ini digunakan untuk membantu menopang benda keras saat berlangsung proses pengelasan [5]. Efisiensi proses pengelasan suatu produk dapat 
ditingkatkan dengan mengurangi waktu persiapan (set up) melalui penggunaan alat bantu fixture dan mampu menjamin hasil pengelasan yang sesuai. Penggunaan alat bantu selain mengurangi waktu persiapan dapat meningkatkan volume produksi sehingga berdampak pada penurunan biaya produksi [6].

Pengertian fixture berfungsi untuk mengarahkan benda kerja, dan melakukan pencekaman pada posisi yang sesuai dan tepat. Pencekaman (clamping) untuk mempertahankan benda kerja pada alat fixture perlu dilakukan proses menempatkan benda kerja dengan benar (locating) [7]. Penggunaan pencekam mampu menghasilkan pengulangan keakuratan hasil. Desain pencekam yang digunakan untuk produksi rangka furnitur penelitian ini mengacu paten dengan nomor US 6.860.475 B2 tentang alat pencekam yang dapat digunakan untuk menahan benda kerja dengan posisi $90^{\circ}$ pada ketiga sumbu [8]. Benda kerja dapat dengan mudah dilepas setelah proses pengelasan selesai. Hasil penelitian ini sebagai acuan data bahwa menggunakan alat bantu pencekam mampu meningkatkan produktifitas pembuatan rangka furnitur. Alat pencekam tidak digunakan pelaku industri furnitur logam skala kecil seperti di Yatno Furniture [9].

\section{MetOde}

Pembuatan desain pencekam tiga aksis berdasarkan model furnitur yang akan diproduksi. Hasil desain pencekam ditunjukkan Gambar 2.1.

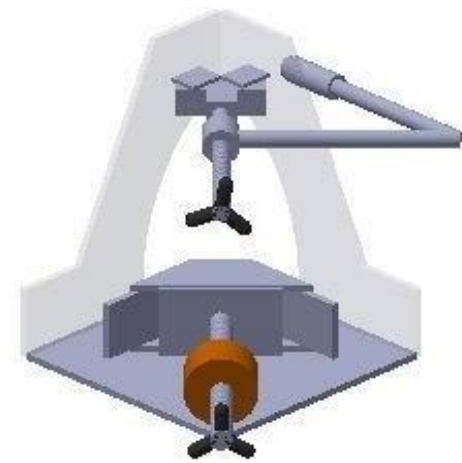

Gambar 2.1 Desain pencekam tiga aksis.

Pembuatan rangka furnitur menggunakan metode las Shield Metal Arc Welding (SMAW) biasa disebut las busur listrik. Benda kerja yang diletakkan pada fixture tersebut membentuk tiga aksis dengan posisi saling tegak lurus $90^{\circ}$. Proses pengelasan dilakukan menggunakan elektroda RD-260, Voltase 20-25 V, serta variasi arus $50 \mathrm{~A}$ dan $60 \mathrm{~A}$. Magnet siku digunakan sebagai penggati alat bantu pencekam, kedua hasil tersebut digunakan untuk kajian hasil rangka furnitur dengan dan tanpa alat bantu pengelasan. Rangka menggunakan bahan besi square hollow dengan ukuran $3 \mathrm{~cm} \times 3 \mathrm{~cm}$ ditunjukkan Gambar 2.2 dibawah ini.

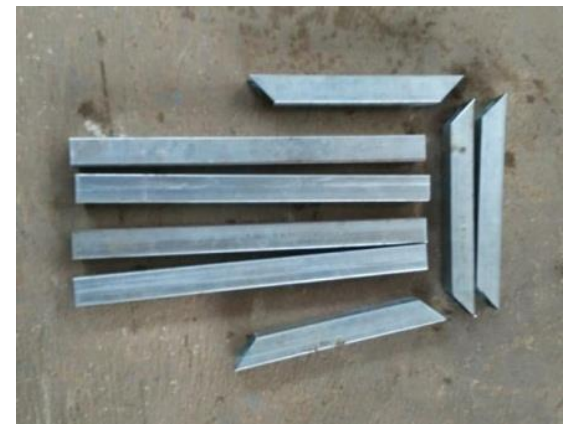

Gambar 2.2 Bahan rangka frame. 


\section{Hasil dan Pembahasan}

\subsection{Perbandingan waktu set up dan proses}

Analisis perbandingan proses perhitungan waktu set up dan proses menggunakan alat bantu Pencekam Tiga Aksis dan tanpa menggunkan Pencekam Tiga Aksis maka diketahui perbandingan waktu setup dan proses, seperti pada Tabel 3.1.

Tabel 3.1 Hasil total waktu pengelasan

\begin{tabular}{lcccc}
\hline Pencekam & $\begin{array}{c}\text { Arus } \\
\text { Las (A) }\end{array}$ & $\begin{array}{c}\text { Waktu } \\
\text { setup } \\
\text { (detik) }\end{array}$ & $\begin{array}{c}\text { Waktu } \\
\text { proses } \\
\text { (detik) }\end{array}$ & $\begin{array}{c}\text { Total } \\
\text { waktu } \\
\text { (detik) }\end{array}$ \\
\hline $\begin{array}{l}\text { Menggunakan } \\
\begin{array}{l}\text { Pencekam } \\
\text { Tiga Aksis }\end{array}\end{array}$ & 50 & 17,44 & 58,72 & 76,16 \\
$\begin{array}{l}\text { Tanpa } \\
\begin{array}{l}\text { Pencekam } \\
\text { Tiga Aksis }\end{array}\end{array}$ & 50 & 18,24 & 55,31 & 73,55 \\
& 60 & 43,12 & 50,72 & 93,84 \\
& 60 & & & \\
\hline
\end{tabular}

Waktu persiapan benda kerja sebelum pengelasan (set up) menjadi lebih cepat dibandingkan tanpa alat bantu. Rata-rata waktu set up dengan pencekam tiga aksis sebesar 17,84 detik, sedangkan tanpa pencekam tiga aksis sebesar 43,35 detik. Proses set up mengalami kenaikan sebesar $58,85 \%$ dibandingkan tanpa alat bantu. Kenaikan ini terjadi juga pada penelitian Hendro (2012)[2] penggunaan jig dan fixture mengurangi waktu set up sebesar $71,5 \%$. Berkurangnya waktu set up juga diungkapkan oleh Pachbhai dkk (2014)[3] dan Syadda (2020)[6]. Pemanfaatan alat bantu pencekam juga mampu mengurangi waktu set up pada pengelasan sambungan $\mathrm{T}$. Proses set up menggunakan pencekam tiga aksis ditunjukkan Gambar 3.1 dan 3.2.

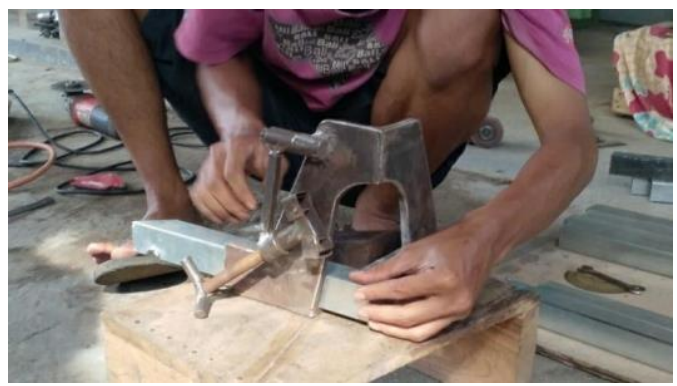

Gambar 3.1. Proses set up menggunakan alat bantu

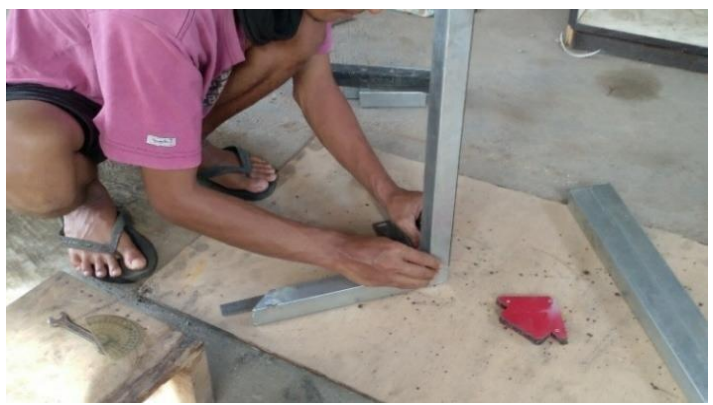

Gambar 3.2 Proses set up tanpa alat bantu 
Pengelasan menggunakan alat bantu pencekam memerlukan waktu $13 \%$ lebih lama dibandingkan tanpa alat bantu. Hal ini disebabkan karena ruang gerak las pada alat bantu lebih sempit dibandingkan dengan tanpa alat bantu pencekam. Penyebab waktu lebih lama dikarenakan operator las baru pertama kali menggunakan alat bantu sehingga belum terbiasa pemanfaatan alat bantu. Proses pengelasan ditunjukkan Gambar 3.3 dan 3.4.

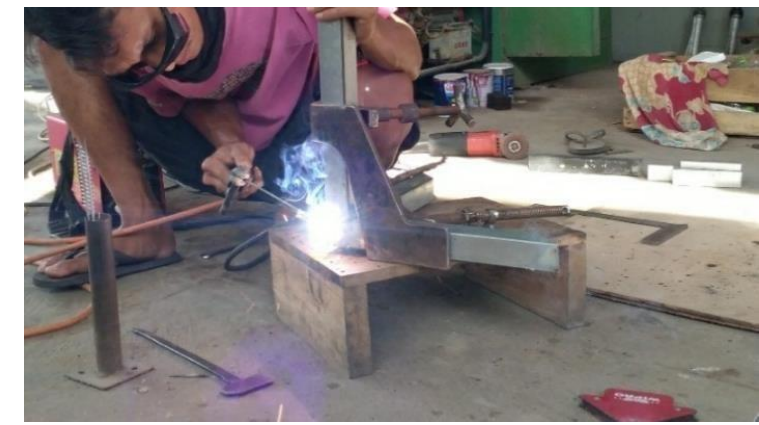

Gambar 3.3 Proses pengelasan menggunakan alat bantu

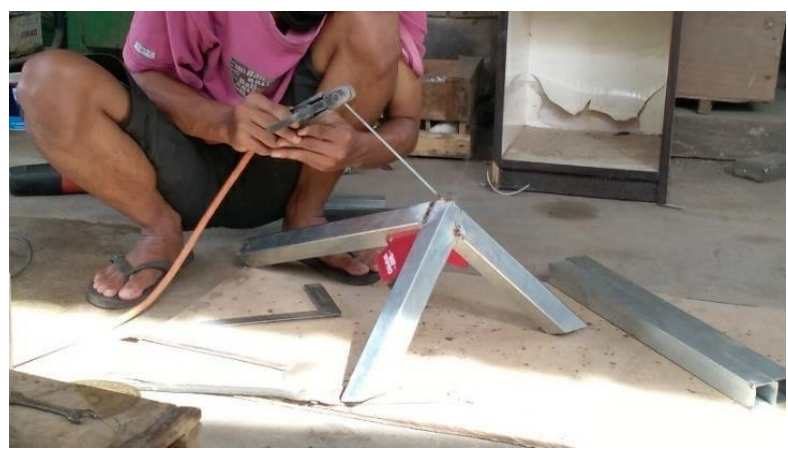

Gambar 3.4 Proses pengelasan tanpa alat bantu

Waktu keseluruhan proses pengelasan rangka furnitur dengan alat bantu 76,84 detik dengan arus 50 Ampere, dan 74,55 detik dengan arus 60 Ampere. Sedangkan tanpa alat bantu pencekam membutuhkan waktu 93,84 detik dengan arus $50 \mathrm{~A}$ dan 93,83 detik dengan arus 60 Ampere. Perbedaan penggunaan arus las listrik tidak berpengaruh signifikan terhadap lama waktu proses pengelasan rangka furnitur. Rata-rata keseluruhan waktu total dari set up dan proses las sebesar 74,85 detik dengan alat bantu dan 93,84 detik tanpa alat bantu pencekam tiga aksis. Penggunaan alat bantu pencekam tiga aksis mampu mengurangi total waktu sebesar $20 \%$ dibandingkan tanpa alat bantu pencekam.

\subsection{Distrosi hasil pengelasan}

Penggunaan pencekam mampu mencegah terjadinya distorsi terhadap hasil pengelasan [10]. Pengujian dengan dan tanpa alat bantu pencekam menghasilkan nilai besar distorsi pengelasan yang berbeda yang ditunjukkan pada Tabel 3.2.

Tabel 3.2 Hasil total waktu pengelasan

\begin{tabular}{cccc}
\hline Pencekam & $\begin{array}{c}\text { Arus } \\
\text { Las (A) }\end{array}$ & Sumbu & $\begin{array}{c}\text { Distorsi } \\
\text { (derajat) }\end{array}$ \\
\hline & \multirow{2}{*}{50} & $\mathrm{x}$ & 0,8 \\
\cline { 2 - 3 } $\begin{array}{c}\text { Menggunakan } \\
\text { Pencekam } \\
\text { Tiga Aksis }\end{array}$ & \multirow{2}{*}{60} & $\mathrm{y}$ & 0,4 \\
\cline { 2 - 4 } & & $\mathrm{z}$ & 0,6 \\
\cline { 2 - 3 } & & $\mathrm{y}$ & 0,5 \\
\cline { 2 - 3 } & & $\mathrm{z}$ & 0,7 \\
\hline
\end{tabular}




\begin{tabular}{|c|c|c|c|}
\hline \multirow{6}{*}{$\begin{array}{c}\text { Tanpa } \\
\text { Pencekam } \\
\text { Tiga Aksis }\end{array}$} & \multirow{3}{*}{50} & $x$ & 2 \\
\hline & & $y$ & 1,6 \\
\hline & & z & 1,6 \\
\hline & \multirow{3}{*}{60} & $x$ & 1,5 \\
\hline & & $y$ & 1,4 \\
\hline & & z & 1,6 \\
\hline
\end{tabular}

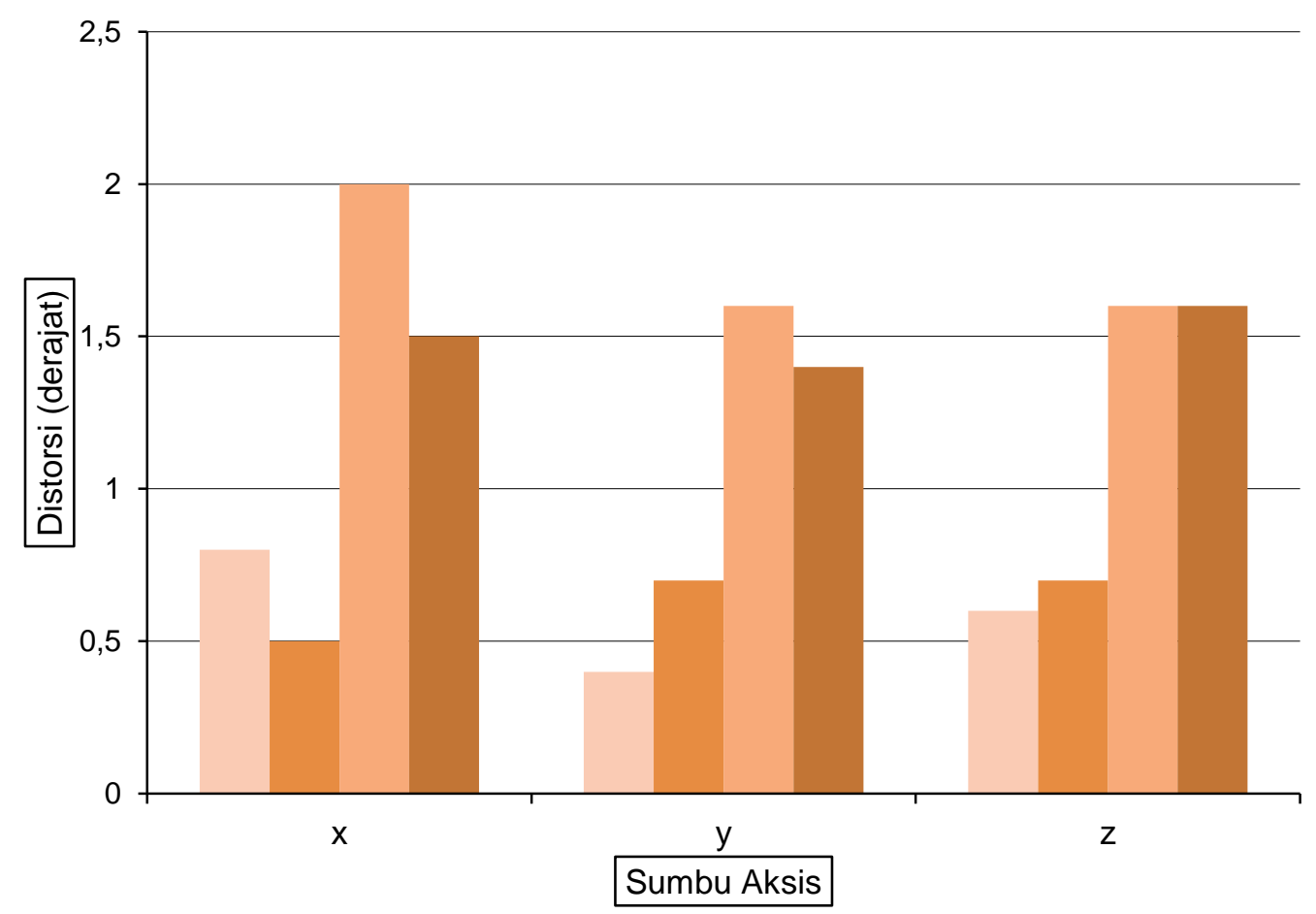

Alat bantu pencekam, arus $50 \mathrm{~A}$

- Alat bantu pencekam, arus $60 \mathrm{~A}$

- Tanpa alat bantu pencekam, arus $50 \mathrm{~A}$

- Tanpa alat bantu pencekam, arus $60 \mathrm{~A}$

Gambar 3.5 Grafik distorsi pada proses pengelasan rangka furnitur

\subsection{Peningkatan Keuntungan Ekonomis}

Analisis perhitungan keuntungan ekonomis dilakukan untuk memberikan data penggunaan alat bantu pencekam tiga aksis mampu meningkatkan keuntungan ekonomis. Pembuatan kursi furnitur memerlukan rangka hasil pengelasan. Waktu yang diperlukan menyelesaikan sebuah rangka dengan menggunakan alat bantu pencekam sebesar 74,85 detik, sedangkan tanpa alat bantu sebesar 93,84 detik. Penghematan waktu produksi hingga $20 \%$ mampu mengurangi biaya operasional tenaga las. Estimasi peritungan keuntungan ekonomis:

a. Menggunakan alat bantu pencekam:
8 jam kerja $\quad=28.800$ detik

Waktu proses $\quad=74,85$ detik $\approx 75$ detik

Dengan asumsi perhitungan ideal selama 8 jam kerja mampu menyelesaikan proses pengelasan 384 rangka

b. Tanpa alat bantu pencekam:
8 jam kerja
$=28.800$ detik
Waktu proses $\quad=93,84$ detik $\approx 94$ detik

Dengan asumsi perhitungan ideal selama 8 jam kerja, mampu menyelesaikan proses pengelasan 306,4 rangka dengan pembulatan 306 rangka. 
Perbedaan jumlah produksi sebanyak 78 buah rangka hasil pengelasan, cukup signifikan menurunkan biaya operasional tenaga las. Asumsi biaya yang harus dikeluarkan untuk tenaga las Rp. 400.000 per 8 jam kerja. Biaya produksi tenaga las dengan alat bantu pencekam Rp 1.042 per frame, sedangkan tanpa alat bantu $\mathrm{Rp} 1.307$ per frame.

\section{KesimpULAN}

Penggunaan alat bantu pencekam tiga aksis terbukti mampu meningkatkan produktifitas pengelasan rangka furnitur. Waktu yang dibutuhkan untuk pembuatan satu set rangka furnitur mengalami kenaikan sebesar $20 \%$ dibandingkan tanpa alat bantu pencekam. Selain kenaikan waktu produksi, kualitas hasil las meningkat ditunjukkan dengan kecilnya nilai distorsi yang terjadi pada ketiga sumbu $(x, y, z)$. Alat bantu pencekam mampu menahan distorsi derajat kelengkungan setelah proses las maksimal sebesar 0,8․, sedangkan tanpa alat bantu terjadi distorsi maksimal sebesar 20 . Peningkatan produktifitas berdampak terhadap biaya operasional tenaga las menjadi lebih murah. Biaya operasional tenaga las mampu ditekan sebesar $20 \%$ untuk satu unit rangka furnitur.

\section{Daftar Pustaka}

[1] S. Ahmaden, "Rancang Bangun Alat Penepat untuk Pengelasan pada Pagar Ranjang Rumah Sakit Ekonomis dengan Metode Meja Putar (Proses Pembuatan)," Politeknik Negeri Sriwijaya, 2014.

[2] H. Prassetiyo, I. R. Ramdhan, J. T. Industri, F. T. Industri, J. P. H. H. Mustofa, and N. Bandung, "Bidang Teknik Mesin Rancangan Welding Fixture Pembuatan Rangka Produk Kursi Prosiding Seminar Nasional Teknoin 2012 ISBN No . 978-979-96964-3-9," no. November, pp. 116-123, 2012.

[3] S. S. Pachbhai and L. P. Raut, "A Review on Design of Fixtures," Int. J. Eng. Res. Gen. Sci., vol. 2, no. 2, pp. 126-146, 2014.

[4] A. I. Komara and F. Syaleh, "Studi Perancangan Welding Fixture untuk Pengelasan Bevel Gear Support dan Motor Drive Support pada Transformator," J. Teknol. dan Rekayasa Manufaktur, vol. 02, pp. 1-8, 2006.

[5] E. G. Hoffman, Jig and Fixture Design Fourth Edition, Fourth. New York: Delmar Publisher Inc, 1996.

[6] A. Syadda and Fusito, "PERANCANGAN DAN PEMBUATAN ALAT BANTU PEGANG ( FIXTURE ) UNTUK PROSES PENGELASAN SAMBUNGAN-T Anhara Syadda dan Fusito Jurusan Teknik Mesin Fakultas Teknik Universitas Sriwijaya Jl . Raya Palembang - Prabumulih Km 32 , Inderalaya ( OI ) Telp / Fax . ( 0711," Universitas Sriwijaya, 2020.

[7] S. N. Shinde, S. Kshirsagar, A. Patil, T. Parge, and R. Lomte, "Design of Welding Fixtures and Positiners," Int. J. Eng. Res. Gen. Sci., vol. 2, no. 5, pp. 681-689, 2014.

[8] D. McBee, "WELDING CLAMP," US 6,349,869 B1, 2002.

[9] Yatno, "Kebutuhan Pembuatan Furnitur Kombinasi Logam dan Kayu," Banjarnegara, 2019.

[10] M. Vural, "The effect of welding fixtures on welding distortions,"June, 2014. 